\title{
Viticulture Zoning in Montenegro
}

\author{
Svetozar SAVIĆ*, Miško VUKOTIĆ \\ Research and Development department, Plantaže ad, Put Radomira Ivanovića, No 2 street, Postal code: \\ 81000, Podgorica, Montenegro \\ *corresponding author: svetozarsavic1@gmail.com
}

Bulletin UASVM Horticulture 75(1) / 2018

Print ISSN 1843-5262, Electronic ISSN 1843-536X

DOI:10.15835/buasvmcn-hort: 003917

\begin{abstract}
Montenegro's viticultural regions and sub-regions were defined in the 2007 Law on Wine, based on the country's empirical, traditional, historical and social heritage. However, during the process of defining these regions and sub-regions, the influence of climatic and soil factors crucial in the determination of dependent characteristics, such as the physiology of the grapevine and the quality of the grapes and wine, was not researched thoroughly enough. This work presents the climatic characteristics of the existing sub-regions, as well as the results of the climate's impact on the physiological reactions of the most common domestic grape cv. Vranac (Vitis vinifera L.), facilitating a new viticultural zoning in Montenegro. Over a period of 56 years, the following climatic parameters were analysed: air temperature, precipitation, insolation and air humidity. These parameters suggest that all the sub-regions in Montenegro have uniform climatic parameters. The modification of certain climatic parameters is influenced by two large bodies of water - the Adriatic Sea and Lake Skadar - and by altitude. The duration of the individual phases and vegetation of the Vranac grape variety differed only slightly in the different sub-regions. As a reflection of the influence of climatic factors in different locations, Vranac grape and wine was analysed chemically and given a sensory evaluation. The analysed parameters indicate a nearly uniform chemical composition and sensory evaluation of all wines. Wines produced at lower altitudes were distinctive for their superior quality.
\end{abstract}

Keywords: Montenegro, viticulture, zoning, grape, wine, climate indeces

\section{Introduction}

Essentially, zoning involves the establishment of boundaries of lower-category areas within the entire viticultural region where similar ampelotechnical methods are implemented.

Although Montenegro is an old European and Mediterranean grape-growing country, due to regaining statehood only in 2006 and its small viticultural region covering only 2,700 hectares (National Bureau of Statistics, 2014), it is facing a zoning problem as a new viticultural country.

After World War II, Montenegro, as a Yugoslav republic, was classified as an Adriatic grapegrowing region, with two sub-regions - the Montenegrin coast and the area of Lake Skadar (Jelaska, 1954; Ulićević, 1959). In the 1970s, the new zoning classified the grape-growing regions into two viticultural zones: the Montenegrin coast and the Titograd area (Grupa autora, 1977).
According to the 2007 Law on Wine, Montenegro's viticultural area is classified into two regions: the Montenegrin Coast and the Lake Skadar basin (Fig. 1).

It is more than obvious that the previous names of the regions have been only slightly changed.

Zoning practices were originally introduced by growers of Old World established wine regions solely to protect their livelihoods (Skelton, 2009). A large number of established grape-growing countries such as France, Italy and Spain completed the zoning of their viticultural territory long ago (Party et al., 1990; Lebon, 1993; Sotés et al., 1994; Falcetti, 1994; Carbonneau, 2000; Tonietto and Carbonneau, 2004; João et al., 2012).

With regard to zoning, New World regions, such as California, Chile, South Africa, Australia and New Zealand use a classification based on 


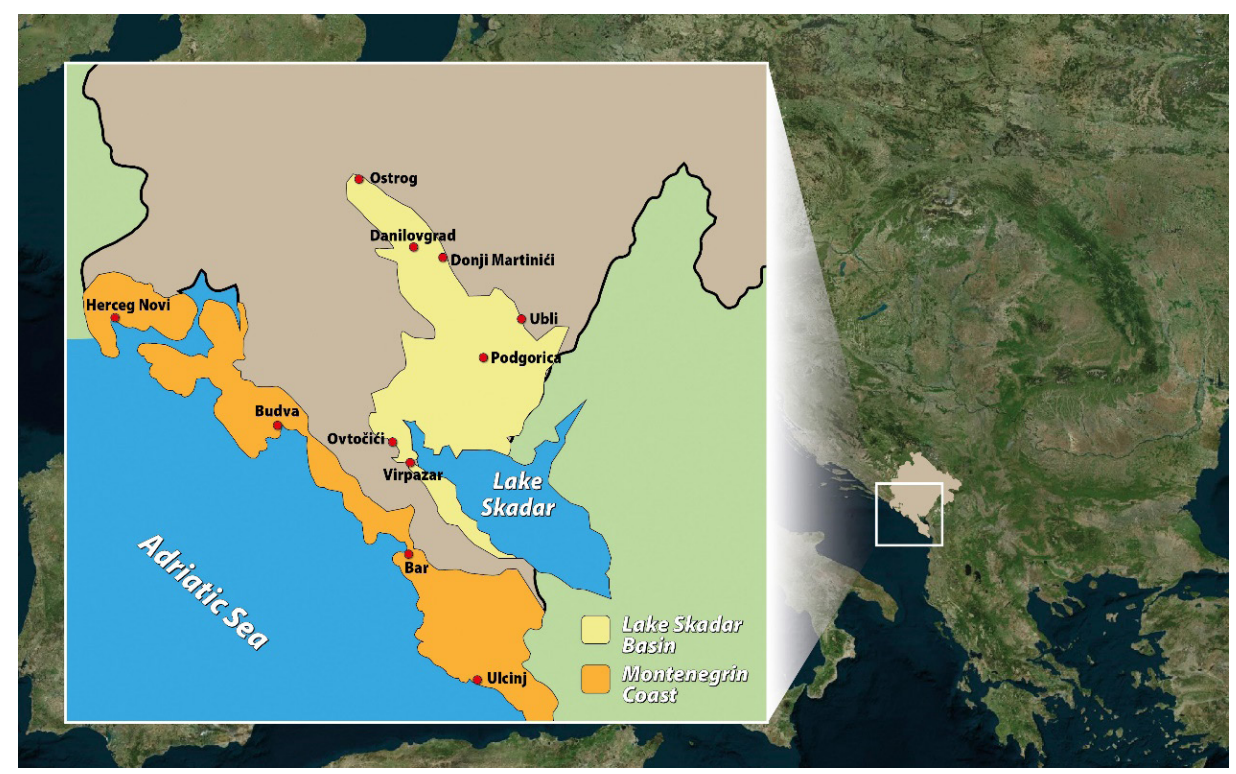

Figure 1. Montenegro and the borders of grape-growing regions

temperature accumulation (degree days), that was proposed by Amerine and Winkler (1944). Today, climate indices have also been introduced (heliothermal, hydrothermal, bioclimatic, etc.), as well as the impact of the soil and the interaction between the soil and the grapevines that affects the quality of the grapes and wine produced (White, 2003). An approach to particular zoning involves analysis using a Geographical Information System (GIS) which incorporates factors related to climate, topography and the soil (Madruga, 2015).

In the process of zoning, phenology is also taken into account (the duration of the ripening of grapes, temperature accumulation and precipitation during the growing season) (Köse, 2014), then the soil's gravel content, as well as the percentage of clay and sand in the soil next to the root system (Carbonneau, 2003, Tesic et al., 2010) and other factors.

Various authors have suggested different aims of zoning: Winkler et al. (1974) stated that the taste of wine in very warm regions is often pungent and raw, while other ingredients are poorly balanced, therefore, these regions can usually produce only dry table wines. Dokoozlian (1996) said that viticulture zoning among wine producers or professional organizations pertains to the spatial characterization of zones that are likely to produce grapes or wines of similar composition, while enabling operational decisions to be implemented at the various stages of production. Vaudour (2003) and Vaudour and Shaw (2005) stated that the demarcation of registered designations of origin or protected geographical indications is one of the most obvious zoning aims.

In New Zealand, Shanmuganathan (2010) used cartography and two main categories that included dependent factors (grape yield and wine quality, but also others), as well as independent factors (climate, environment, etc.). The factors of both categories were analyzed using historical, biotic and modelling data, thereby enabling producers to understand and predict the reaction of grapevines to different impacts.

Gridded daily precipitation totals and daily minimum, mean and maximum air temperatures across Europe were used for the bioclimatic index calculations (Santos et al., 2012), and the application of the EFI index (ecological favourability index) for the evaluation of the favorability for ecological viticulture (Antoce et al., 2007).

Digital mapping methods and remote sensing techniques have revolutionized viticultural zoning at all levels, ranging from individual plots to the regional level.

However, none of these classifications can be accepted or applied unconditionally. A large number of environmental factors act in unison, reducing or increasing the intensity of each of them. Also, one should not forget that the climate is a dynamic category. We see, depending on the geographical position (Popescu, 2011), that microclimate changes vary significantly within a single 


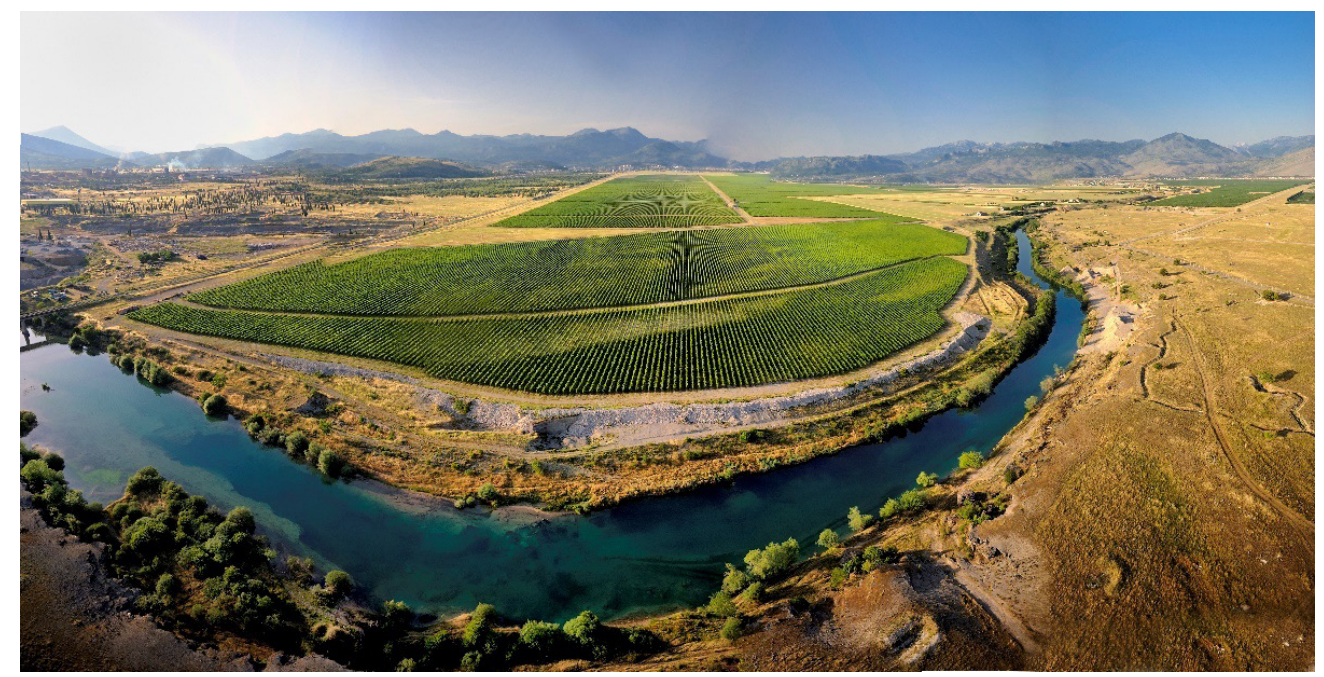

Figure 2. Vineyards of the company Plantaže

vineyard over the course of a year, and climate change, in recent years, has been affecting not only the implementation of ampelotechnical measures in an individual vineyard (Savić and Petranović, 2004; Jukić et al., 2013), but also changes in the zoning of a grape and its quality, as well as the entire agriculture industry. In various studies (Jones et al., 2005; Neumann and Matzarakis, 2011; Fraga et al., 2013) temperature changes (an increase of $2^{\circ} \mathrm{C}$ over the next 50 years), periods of drought, especially across southern and western Europe, and a significant impact on the quality of wines were emphasized.

The goal of this work is to officially define wine-growing areas, study the climatic impacts on the physiology and quality of Vranac grapes and wine, the most widespread grape variety in Montenegro, as well as to find justification for the existing zoning.

\section{Materials and methods \\ Viticultural zone of Montenegro}

Montenegro, within its present borders, is situated between the latitudes of $41^{\circ} 52^{\prime}$ and $43^{\circ} 32^{\prime} \mathrm{N}$ and the longitudes of $18^{\circ} 26^{\prime}$ and $20^{\circ} 21^{\prime} \mathrm{E}$. Intensive cultivation of grapes takes place only in the central and southern parts of the country and up to an altitude of $400 \mathrm{~m}$. The relief is defined by many relatively small and diverse landforms, the influence of two large water bodies (the Adriatic Sea and Lake Skadar) and altitude, all of which have a significant role in the formation of the climate regime of the region of Montenegro (Savić, 2004a, 2004b).
The centre of viticulture, which includes both the public and private sectors, is located in the vicinity of Podgorica and Lake Skadar. Plantaže, a state-owned company, dominates here with 2,300 ha in its possession (Fig. 2).

The company cultivates a large number of grape varieties important for the production of wines (Vranac, Krstač, Kratošija, Cabernet Sauvignon, Merlot and Chardonnay) and table grapes (Cardinal, Ribier, Muscat Italy, etc.).

In the region of Lake Skadar basin, grapes are cultivated at even higher altitudes $(\approx 450 \mathrm{~m})$; in the coastal region, they mainly grow at lower altitudes, near the sea. The areas at higher altitudes are used for the development of the tourist infrastructure, hotels and apartments.

Besides the state-owned company Plantaže, in recent years private wine cellars have also been increasingly planting varieties (Chardonnay, Malvasia, Sauvignon Blanc and Krstac) for the production of white wines. In the cellars for production and aging of both red and white wines, barrique barrels are increasingly being used. Also, private wine cellars are paying particular attention to the appearance of their labels and bottles, as well as to marketing.

In 2014, the total grape production was 17,128 tons and wine production reached 99,981 hL (National Bureau of Statistics, 2014).

\section{Plant material}

It is believed that the local Vranac variety (Vitis vinifera L.) was created by free crossbreeding in nature. The variety can be found in all the sub- 
regions of Montenegro and is also the dominant grapevine in the company Plantaže (Savić, 2016). It covers $80 \%$ of the viticultural area in Montenegro. Its grapes ripen in September (medium-lateripening variety) and serves as the basis for the production of wine and brandy.

The results produced by Bulić (1949) show that the Vranac cultivar in the Bay of Kotor (Montenegro) has a high or very high yield and with irrigation this reaches over $25,000 \mathrm{~kg} / \mathrm{ha}$. In his experiments on Vranac in Ljeskopolje (near Podgorica), Ulicević (1966) states that the clusters per fruiting cane is 1.34, the grapes develop on average $23.4{ }^{\circ} \mathrm{Bx}$ of sugar, and the clusters have an average weight of $264.5 \mathrm{~g}$. Burić (1995) states that for the Vranac variety in the conditions of Podgorica, the average number of clusters per fruiting cane was 1.56. According to the same author, the wine Vranac contains on average 12$13 \%$ alcohol and 5.0-6.5 g/L of total acids.

\section{Climatic data and parameters}

Climatic data for the period from 1950 to 2005 (a 56-year span) was taken from the weather stations of the Institute for Hydrometeorology and Seismology of Montenegro at six locations (Herceg Novi, Bar, Ulcinj, Virpazar, Podgorica and Danilovgrad).

On the basis of the data for these locations, the following parameters were calculated: average annual temperature, average temperature during the growing season, minimum and maximum air temperatures, annual temperature fluctuations, insolation, annual rainfall and air humidity during the growing season.

The assessment of climatic conditions was carried out by analysing the Sum of Effective Temperatures (Amerine and Winkler, 1944):

$\mathrm{WI}=\sum\left[\left(\mathrm{T}_{\max }+\mathrm{T}_{\min }\right) / 2\right]-10$

in which: WI is the Winkler Index $\left({ }^{\circ} \mathrm{C}\right)$; $\mathrm{T}_{\max }$ is the maximum temperature calculated for the period $1 \mathrm{Apr}-31$ Oct $\left({ }^{\circ} \mathrm{C}\right) ; \mathrm{T}_{\min }$ is the minimum temperature calculated for the period $1 \mathrm{Apr}-$ 31 Oct $\left({ }^{\circ} \mathrm{C}\right)$;

Huglin's Heliothermal Index (Huglin, 1978):

$\mathrm{HI}=\sum \frac{\left[\left(T_{\text {avg }}-10\right)+\left(T_{x}-10\right)\right]}{2} \cdot \mathrm{k}$

in which: $\mathrm{HI}$ is the Huglin Heliothermal Index $\left({ }^{\circ} \mathrm{C}\right)$; $\mathrm{T}_{\text {avg }}$ is the average temperature calculated for the period $1 \mathrm{Apr}-30 \operatorname{Sept}\left({ }^{\circ} \mathrm{C}\right) ; \mathrm{T}_{\max }$ is the maximum temperature calculated for the period $1 \mathrm{Apr}-$
30 Sept $\left({ }^{\circ} \mathrm{C}\right)$; $\mathrm{k}$ is the length-of-day coefficient ( $41^{\circ}$ to $50^{\circ}$ calculated as 1.025 );

Selianinov's Hydrothermal Coefficient (Seljaninov, 1966):

$\mathrm{HTC}=\left[10 \sum \mathrm{P}_{\mathrm{i}}\right] /\left[\sum \mathrm{T}_{\mathrm{i}}\left(\mathrm{T} \geq 10{ }^{\circ} \mathrm{C}\right)\right]$

in which: HTC is the Hydrothermal Coefficient; $\mathrm{P}_{\mathrm{i}}$ is the precipitation for the period $1 \mathrm{Apr}-30 \mathrm{Sept}$ $(\mathrm{mm}) ; \mathrm{T}_{\mathrm{i}}$ is the average temperature above 10 ${ }^{\circ} \mathrm{C}$; $i$ is the number of days from 1 Apr to 30 Sept;

Branas' Heliothermal Index (Branas, 1974):

$\mathrm{HTK}=\sum\left[\left(\mathrm{T}_{\mathrm{avg}}-10\right) \cdot \mathrm{I}_{\mathrm{e}} \cdot 10^{-6}\right]$

in which: HTK is the Heliothermal Index; $\mathrm{T}_{\text {avg }}$ is the average temperature calculated for the period $1 \mathrm{Apr}-30 \mathrm{Sept}\left({ }^{\circ} \mathrm{C}\right)$; $\mathrm{I}_{\mathrm{e}}$ is the effective insolation, calculated for the period 1 Apr to 30 Sept (hours);

Constantinescu's bioclimatic index

(Constantinescu, 1970):

$\mathrm{BCI}=\left(\sum \mathrm{T} \cdot \mathrm{I}_{\mathrm{e}}\right) /\left(\mathrm{P}_{\mathrm{i}} \cdot i \cdot 10\right)$

in which: $\mathrm{BCI}$ is the bioclimatic index; $\mathrm{T}$ is the temperature for the period $1 \mathrm{Apr}$ to $30 \mathrm{Sept}\left(^{\circ}\right.$ C); $\mathrm{P}_{\mathrm{i}}$ is the precipitation for the period $1 \mathrm{Apr}$ to 30 Sept $(\mathrm{mm})$; $\mathrm{I}$ is the effective insolation calculated for the period 1 Apr - 30 Sept (hours); $i$ is the number of days from $1 \mathrm{Apr}$ to $30 \mathrm{Sept}$.

\section{Soil parameters}

Geologically observed, the viticultural region of Montenegro is formed by rocks of different composition and age. In this region carbonaceous rocks such as limestone, dolomitic limestone and dolomite dominate (Fuštić and Đuretić, 2000). The formation of the soil on these rocks results in changed physical and chemical properties that go on to affect the growth and grape yield.

On the whole, in the continental part of the wine-growing region (Podgorica, Danilovgrad and Virpazar) red clays (terra rossa), brown eutric soils and diluvium prevail, while alluvial and swampy soils are present around Lake Skadar. In the narrow strip of the coastal region the situation is similar. In this area, from Herceg Novi to Ulcinj, brown eutric soils dominate, then red clays, and brown acidic soils, as well as rankers in the Bay of Kotor.

In order to reduce the influence of various soil factors, we selected those vineyards that are planted in terra rossa. It is a dominant viticultural soil of different depths and composition. Chemical analysis $\left(\mathrm{pH}\right.$, active $\mathrm{CaCO}_{3}$, organic matter content, $\mathrm{K}$ and $\mathrm{P}$ content) and physical analysis (sand, clay) 
of the soils were carried out in the Laboratory for Pedology of the Biotechnical Faculty in Podgorica. Soils were described using the Classification of Soils of Yugoslavia (Škorić et al., 1985) and the analyses of Fuštić and Djuretic (2000). The samples were taken from three depths (0 to 20, 20 to 40 and 40 to $60 \mathrm{~cm}$ ).

Viticultural and oenological measurements

Five grapevines were chosen for observation at each location. They were grafted onto 5BB, and trained on a double cordon system.

Spur pruning was applied to every vine at every location. The number of retained buds was the same (20 buds per vine) throughout the experimental years. The number of clusters per fruiting cane was determined during vegetation. At each location the grape harvest took place when the sugar content had reached 21-22 ${ }^{\circ} \mathrm{Bx}$. The number of clusters and average weight was determined after harvesting using the OIV descriptor list (OIV, 2001). During the winter and after pruning we measured the pruning weight per vine, then we calculated the fruit pruning ratio (F/P) according to the Ravaz formula (Ravaz, 1912).

The results of the grape and wine investigation are shown at the level of average values and total forms using analyses of variance $(\mathrm{Cv} \%)$ and an LSD test at $\mathrm{p}=0.05$ to compare the means of treatment.

The grapes were harvested in nine vineyards: Herceg Novi - one sample, Bar - one sample, Ulcinj - one sample [the Montenegrin Coast]; Virpazar - two samples (locations: Godinje and Ovtočići), Podgorica - two samples (locations: Balijače and Ubli) and Danilovgrad - two samples (locations: Lower Martinići and Ostrog) [Lake Skadar basin], of which the vineyards from Ovtočići, Ubli and Ostrog were located at higher altitudes (> $350 \mathrm{~m}$ ).

Data on the phenological stages (budburst, flowering, véraison, harvesting and leaf-fall) were collected during the period from 2005 to 2007. The dates were recorded following the OIV's methods (2001). In all locations, the harvesting started when the sugar content in grapes reached 21 to $22^{\circ} \mathrm{Bx}$. The sugar content in the grapes was determined by a manual refractometer (RHB 32 ATC). The aim was to determine the number of days that are necessary for grapes to reach this sugar content, and to have comparability with the quality of the must and wine in other locations. The analysis of wines was carried out to define the following parameters: specific gravity (using a Morhovscale densitometer), alcohol content (distillation with Gibertini apparatus - a distiller - according to Jolmes), total extract (using a Windisch table), then the $\mathrm{pH}$ (using a $785 \mathrm{DMP}$ Titrino $\mathrm{pH}$ meter) of the total acid (using a neutralising solution of 0.1 $\mathrm{M} \mathrm{NaOH}$ ) shown as tartaric acid, as well as volatile acid (neutralisation with $\mathrm{NaOH}$ distillate $\mathrm{N} / 7.5$ ).

Micro-vinification was carried out according to the standard procedures of International Code of Oenological practices (OIV, 2004) for each location and particular altitude. Sensory analyses were carried out three months after the wines finished their malolactic fermentation (February). The wines were evaluated by five judges from the University of Belgrade (Viticulture Department), the Association of Sommeliers of Montenegro and the Development Sector of Plantaže, on a scale of up to 100 points by OIV standards (1994).

\section{Results and discussion}

General climatic characteristics of Montenegrin viticulture zone

The data for the period (1950 to 2005) is shown in Table 1, while the data that relates to the research period (2005 to 2007) is presented in Table 2.

The climate in the Lake Skadar basin is influenced by the lake and in the coastal region by the Adriatic Sea. Overall, summers are hot and dry, and winters are mild and rainy with occasionally strong winds. The longer series of data (1950 to 2005 ) indicates that the average of the annual temperatures on the coast was uniform $\left(15.8^{\circ} \mathrm{C}\right.$ to $16.0^{\circ} \mathrm{C}$ ). Within the Lake Skadar basin, the sub-region of Podgorica is the warmest, with an average temperature of $15.6^{\circ} \mathrm{C}$, while the subregions of Virpazar and Danilovgrad are colder $\left(14.3^{\circ} \mathrm{C}\right.$ and $14.5^{\circ} \mathrm{C}$ respectively).

During the growing season, the average temperatures are similar and range between $19.5^{\circ} \mathrm{C}$ and $21.1^{\circ} \mathrm{C}$. However, in the Lake Skadar basin, the maximum temperatures are higher $\left(36.5^{\circ} \mathrm{C}\right.$ to $\left.37.6^{\circ} \mathrm{C}\right)$, compared with the coast $\left(33.1^{\circ} \mathrm{C}\right.$ to $\left.34.7^{\circ} \mathrm{C}\right)$. The influence of the Adriatic Sea is obvious here, which acts as a cooling factor. In both regions, the hottest months are June, July and August.

The influence of the Adriatic Sea reflects in the value of the minimum temperatures that are 
Table 1. Climate parameters in the viticultural zones of Montenegro (average 1950 to 2005)

\begin{tabular}{ccccccc}
\hline & & Coast & \multicolumn{3}{c}{ Lake Skadar basin } \\
\hline Climate characteristics & H.Novi & Bar & Ulcinj & Danilovgrad & Podgorica & Virpazar \\
\hline Average annual temperature $\left({ }^{\circ} \mathrm{C}\right)$ & 16.0 & 15.8 & 15.8 & 14.5 & 15.6 & 14.3 \\
\hline Average growing season temperature $\left({ }^{\circ} \mathrm{C}\right)$ & 20.1 & 19.8 & 20.3 & 19.8 & 21.1 & 19.5 \\
\hline Maximum air temperature $\left({ }^{\circ} \mathrm{C}\right)$ & 34.3 & 33.1 & 34.7 & 37.1 & 37.6 & 36.5 \\
\hline Minimum air temperature $\left({ }^{\circ} \mathrm{C}\right)$ & -0.3 & -1.6 & -1.4 & -6.2 & -4.3 & -5.4 \\
\hline Annual air temperature fluctuation $\left({ }^{\circ} \mathrm{C}\right)$ & 34.0 & 31.0 & 33.3 & 43.3 & 41.9 & 41.9 \\
\hline Annual real insolation $(\mathrm{h})$ & 2,401 & 2,548 & 2,547 & 2,401 & 2,476 & 2,350 \\
\hline Real insolation during growing season $(\mathrm{h})$ & 1,829 & 1,880 & 1,859 & 1,860 & 1,817 & 1,865 \\
\hline Annual rainfall $(\mathrm{mm})$ & 1,860 & 1,362 & 1,207 & 2,210 & 1,641 & 2,156 \\
\hline Rainfall during growing season $(\mathrm{mm})$ & 777 & 607 & 526 & 915 & 702 & 839 \\
\hline Air humidity $(\%)$ & 71 & 69 & 68 & 71 & 64 & 74 \\
\hline
\end{tabular}

Table 2. Climate parameters in the viticultural zone of Montenegro (average 2005 to 2007)

\begin{tabular}{ccccccc}
\hline & \multicolumn{3}{c}{ Coast } & \multicolumn{3}{c}{ Lake Skadar basin } \\
\hline Climate characteristics & H. Novi & Bar & Ulcinj & Danilovgrad Podgorica & Virpazar \\
\hline Average annual temperature $\left({ }^{\circ} \mathrm{C}\right)$ & 16.2 & 16.6 & 15.6 & 14.7 & 16.1 & 14.4 \\
\hline Average growing season temperature $\left({ }^{\circ} \mathrm{C}\right)$ & 20.8 & 21.1 & 20.7 & 20.4 & 22.0 & 19.5 \\
\hline Maximum air temperature $\left({ }^{\circ} \mathrm{C}\right)$ & 35.3 & 34.5 & 37.2 & 40.1 & 41.3 & 38.5 \\
\hline Minimum air temperature $\left({ }^{\circ} \mathrm{C}\right)$ & -1.2 & -1.4 & -2.8 & -8.0 & -5.5 & -7.6 \\
\hline Annual air temperature fluctuation $\left({ }^{\circ} \mathrm{C}\right)$ & 36.5 & 35.9 & 40.0 & 48.1 & 46.8 & 46.1 \\
\hline Annual real insolation $(\mathrm{h})$ & 2,451 & 2,591 & 2,786 & 2,455 & 2,476 & 2,388 \\
\hline Real insolation during growing season $(\mathrm{h})$ & 1,844 & 1,902 & 1,999 & 1,833 & 1,839 & 1,835 \\
\hline Annual rainfall $(\mathrm{mm})$ & 1,839 & 1,411 & 1,228 & 2,087 & 1,667 & 2,194 \\
\hline Rainfall during growing season $(\mathrm{mm})$ & 794 & 576 & 522 & 723 & 645 & 820 \\
\hline Air humidity $(\%)$ & 75 & 65 & 71 & 73 & 61 & 74 \\
\hline
\end{tabular}

higher in the Lake Skadar basin $\left(-4.3^{\circ} \mathrm{C}\right.$ to $\left.-6.2^{\circ} \mathrm{C}\right)$. In both regions, the coldest months are December, January and February, but they cannot harm the vines during the dormant period or during the activation of buds, which begins in April. Over the course of a year, the period without frost, on average, totals 214 days. The coastal region has lower temperature fluctuations during the year $\left(34.0^{\circ} \mathrm{C}\right.$ for Herceg Novi, $31.0^{\circ} \mathrm{C}$ for Bar and $33.3^{\circ} \mathrm{C}$ for Ulcinj). The highest annual temperature fluctuation is in the sub-region of Danilovgrad $\left(43.3^{\circ} \mathrm{C}\right.$ at the northernmost point).

The annual insolation (between 2,401 and 2,548 hours), as well as vegetative insolation (between 1,817 and 1,880 hours) in Montenegro's viticultural zone, over the 56-year series, is uniform for all sub-regions and more than sufficient for the ripening of grapes of the Vranac variety. The average daily sunshine duration over the course of a year is 6.8 hours on the coast, and 6.6 hours in the Lake Skadar basin.

According to Köse (2014), optimal growth requires a minimum annual sunshine duration of between 1,500 and 1,600 hours and a minimum sunshine duration of between 1,200 and 1,400 hours during the phenological cycle.

Over the 56-year period, precipitation reaches its maximum between November and January, and its minimum between June and August. During the year, the highest rainfall is recorded in Danilovgrad $(2,210 \mathrm{~mm}$, on the northern boundary and under the influence of the continental part) and in Virpazar $(2,156 \mathrm{~mm}$, under the influence of Lake Skadar). However, during the growing season, from April to October, the amount of precipitation ranges from $525 \mathrm{~mm}$ (Ulcinj, southernmost point) 


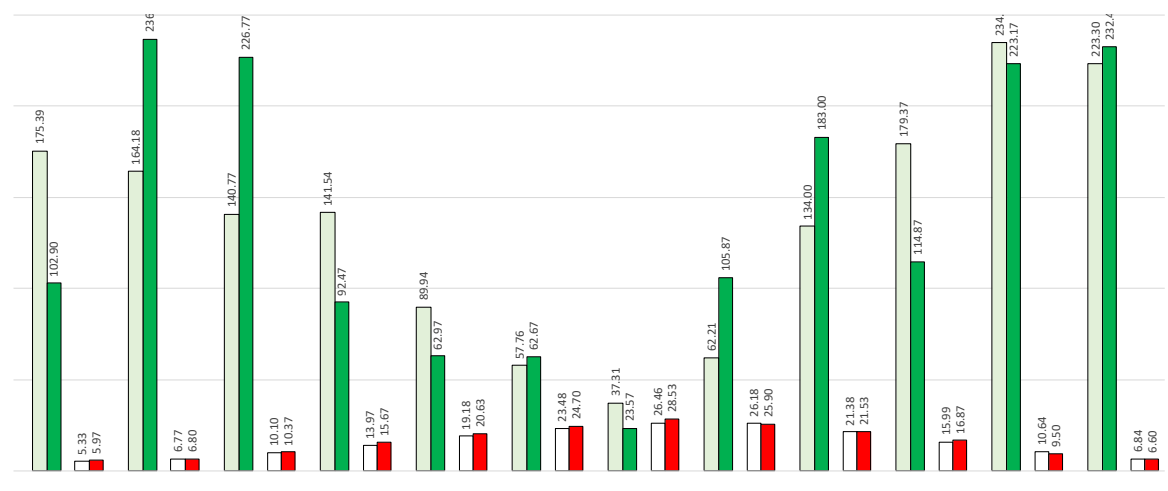

Figure 3. Climatic data relating to temperatures and precipitation in 1950 to 2005 compared to 2005 to 2007 for Podgorica

to $915 \mathrm{~mm}$ (Danilovgrad, northernmost point). The amount of precipitation is much lower on the coast over the year (Bar - 1,362 mm and Ulcinj - 1,207 mm), with the exception of Herceg Novi, where the annual precipitation is $1,829 \mathrm{~mm}$. Above Herceg Novi, in the village of Krivošije, the highest amount of precipitation in Europe is recorded $(5,000 \mathrm{~mm})$. During the warmest months (June, July and August) the rainfall is below 10\% of the total annual amount of precipitation, or on average $60 \mathrm{~mm}$ per month. The lowest amount of precipitation falls in the southernmost sub-region (Ulcinj- $115 \mathrm{~mm}$, or $40 \mathrm{~mm}$ per month). Humidity is uniform $(68 \%$ to $74 \%)$ in all sub-regions, except in Podgorica which has a slightly lower value (64\%).

Comparing the data of the 56-year series with the data from the research period (2005 to 2007), it is clear that all the climatic parameters slightly increased (Fig. 3). Thus, the average annual temperature is $0.2^{\circ} \mathrm{C}$ to $0.8^{\circ} \mathrm{C}$ higher in the coastal region and $0.1^{\circ} \mathrm{C}$ to $0.5^{\circ} \mathrm{C}$ higher in the Lake Skadar basin. The same applies to temperatures during the growing season $\left(0.4^{\circ} \mathrm{C}\right.$ to $1.3^{\circ} \mathrm{C}$ higher at the coast and $0.6^{\circ} \mathrm{C}$ to $0.9^{\circ} \mathrm{C}$ higher by Lake Skadar). The maximum temperatures also rose, particularly in the Lake Skadar basin: in Podgorica by $3.7^{\circ} \mathrm{C}$ and in Danilovgrad by $3.0^{\circ} \mathrm{C}$. In the coastal region, the highest temperature rise was recorded in the southernmost sub-region of Ulcinj (an increase of $2.5^{\circ} \mathrm{C}$ ). The annual temperature fluctuations increased in all sub-regions. A larger difference is recorded on the coast (ranging from $2.5^{\circ} \mathrm{C}$ in Herceg Novi to $6.7^{\circ} \mathrm{C}$ in Ulcinj) than in the LakeSkadar basin (from $4.2^{\circ} \mathrm{C}$ in Virpazar to $4.9^{\circ} \mathrm{C}$ in Podgorica). The duration of sunshine over the year and the period of growth have increased most in Ulcinj (by 239 and 140 hours respectively). The annual amount of precipitation over the period 2005 to 2007 does not differ not so much from the 56-year series. A lower amount of precipitation fell during the growing season. However, it is important to point out that precipitation was far more characterised by downpours, which especially occurred in September, when the amount of rainfall ranged between 120 and $250 \mathrm{~mm}$, which was 40 to $60 \mathrm{~mm}$ higher than the amount in the 56-year series. The data on air humidity is similar to the values of the 56-year series.

\section{Climatic indices}

If we apply the Winkler Index (WI) that refers to the 56-year temperature series (1950 to 2005) to the coastal region and the Lake Skadar basin during the period from 1 April to 31 October, then the Podgorica sub-region can be classified as zone $V$ (hot) (Tab. 3), with the highest sum of effective temperatures $\left(2,361^{\circ} \mathrm{C}\right)$, making it the most favourable in terms of cultivation of grape varieties with different ripening periods. All the other subregions (Herceg Novi, Bar, Ulcinj, Danilovgrad and Virpazar) belong to zone IV (moderately warm). The sub-region of Ulcinj, with its sum of effective temperatures $\left(2,198^{\circ} \mathrm{C}\right)$, is very close to zone $\mathrm{V}$.

The values of the WI relating to the research period (2005 to 2007) differ from the 56-year series (Tab. 4). Therefore, all the sub-regions, according to the WI can be classified into zone 
Table 3. Climatic indices (average 1950 to 2005)

\begin{tabular}{ccccccc}
\hline & \multicolumn{3}{c}{ Coast } & \multicolumn{3}{c}{ Lake Skadar basin } \\
\hline CLIMATIC INDICES & H. Novi & Bar & Ulcinj & Danilovgrad & Podgorica & Virpazar \\
\hline Winkler Index & 2,174 & 2,132 & 2,198 & 2,106 & 2,361 & 2,033 \\
\hline Branas Heliothermic Index & 4.70 & 4.81 & 5.08 & 4.67 & 5.38 & 4.46 \\
\hline Seleaninov Hydrothermic Index & 1.33 & 1.04 & 1.03 & 1.50 & 1.12 & 1.39 \\
\hline Huglin Index & 2,908 & 2,812 & 2,947 & 3,126 & 3,295 & 3,031 \\
\hline Bioclimatic Index & 5.54 & 7.37 & 8.82 & 5.02 & 6.51 & 5.18 \\
\hline
\end{tabular}

Table 4. Climatic indices (average 2005 to 2007)

\begin{tabular}{ccccccc}
\hline & \multicolumn{3}{c}{ Coast } & \multicolumn{3}{c}{ Lake Skadar basin } \\
\hline CLIMATIC INDICES & H. Novi & Bar & Ulcinj & Danilovgrad & Podgorica & Virpazar \\
\hline Winkler Index & 2,448 & 2,447 & 2,321 & 2,515 & 2,815 & 2,186 \\
\hline Branas Heliothermal Index & 5.00 & 5.55 & 5.69 & 5.05 & 5.82 & 4.53 \\
\hline Selianinov Hydrothermic Index & 1.49 & 1.04 & 1.02 & 1.44 & 1.18 & 1.61 \\
\hline Huglin Index & 3,102 & 3,115 & 3,165 & 3,419 & 3,667 & 3,207 \\
\hline Bioclimatic Index & 5.73 & 8.18 & 8.91 & 6.23 & 7.36 & 4.93 \\
\hline
\end{tabular}

$\mathrm{V}$ (hot). The maximum increase in the WI was recorded in Podgorica and Danilovgrad.

The Branas Heliothermal Index (BHI) points to the advantage of vineyard insolation, the adaptability of varieties through the course of their phenological stages and grape ripening. The temperature range optimal for grape cultivation is $2.8^{\circ} \mathrm{C}$ to $4.5^{\circ} \mathrm{C}$. It is believed that the cultivation of grapes is not possible where the heliothermal index is lower than 2.6 (Carbonneau, 2003). As for the 56-year series, the BHI index for the coast was (4.70-5.08 hours), and for the Lake Skadar basin was 4.46 to 5.38 hours. High solar radiation is particularly recorded in Podgorica (5.38 hours) and Ulcinj (5.8 hours).

During the research period (2005 to 2007) the BHI for all sub-regions exceeded the value of 5. Therefore, the same sub-regions differed again according to the value of the BHI: Podgorica (5.82) and Ulcinj (5.69).

The Selianinov Hydrothermic Index is used to determine the quantities of water in the soil that are essential for the growth of grapes, particularly in the warmer part of the year, for example, from May to September. The values usually range between 0.4 and 2.0, and lower values correspond to drier conditions. Thus, values below 0.7 indicate a drought, and those between 0.7 and 1.0 point to a moderately dry summer. The Selianinov index relating to the 56-year series indicates the effect of a mild drought, especially in Ulcinj (1.03), Bar (1.04) and Podgorica (1.12).

During the research period (2005 to 2007) the Selianinov index additionally decreased in Ulcinj and Danilovgrad (Tab. 4). In recent years, precipitation was far more characterised by downpours. Therefore, heavy rain in September was damaging to the ripening and harvesting of grapes. Only in September, when Vranac grapes ripen and are harvested, the amounts of rainfall, on average, were: $132 \mathrm{~mm}$ (Bar), $147 \mathrm{~mm}$ (Ulcinj), $151 \mathrm{~mm}$ (Herceg Novi), $183 \mathrm{~mm}$ (Podgorica), $193.8 \mathrm{~mm}$ (Virpazar) and $195 \mathrm{~mm}$ (Danilovgrad). These figures do not indicate that Montenegrin vineyards are well provided with water. On the contrary, during June, July and August, the conditio sine qua non is the use of irrigation systems.

The Huglin Index (HI) provides information on the thermal and insolation potentials of an area in terms of the ripening of grapes of different varieties (Huglin, 1978). According to the 56 -year indicators, the Lake Skadar basin belongs to the class $\mathrm{H}+3$ (very warm) with an index that ranges from 3,031 to 3,295 units. Again, the sub-region of Podgorica is a leader in terms of the total sum of temperatures $\left(3,295^{\circ} \mathrm{C}\right)$. With regard to the $\mathrm{HI}$ index, there is no fear that the grapes will not ripen in this sub-region. The region of the coast belongs 
Table 5. Average date of phenological stages for different locations (2005 to 2007)

\begin{tabular}{cccccc}
\hline Location & Budburst & Blooming & Véraison & Harvesting & Leaf fall \\
\hline Herceg Novi & $03-30$ & $05-27$ & $07-11$ & $09-05$ & $11-15$ \\
\hline Bar & $03-31$ & $05-28$ & $07-11$ & $09-06$ & $11-15$ \\
\hline Ulcinj & $03-29$ & $05-26$ & $07-10$ & $09-03$ & $11-16$ \\
\hline Virpazar/Godinje & $04-02$ & $05-28$ & $07-13$ & $09-07$ & $11-16$ \\
\hline Virpazar/Ovtocici (300 m alt.) & $04-07$ & $06-03$ & $07-14$ & $09-18$ & $11-09$ \\
\hline Podgorica/Balijače & $03-31$ & $05-27$ & $07-10$ & $09-01$ & $11-14$ \\
\hline Podgorica/Ubli (470 m alt.) & $04-05$ & $06-04$ & $07-14$ & $09-20$ & $11-08$ \\
\hline Danilovgrad/Donji Martinići & $04-01$ & $05-28$ & $07-14$ & $09-08$ & $11-12$ \\
\hline Danilovgrad/Ostrog (400 m alt.) & $04-08$ & $06-05$ & $07-15$ & $09-20$ & $11-10$ \\
\hline
\end{tabular}

to the class $\mathrm{H}+2$ (warm) with a fairly uniform sum of temperatures, from $2,812^{\circ} \mathrm{C}$ to $2,947^{\circ} \mathrm{C}$. In the coastal region, the sub-region of Ulcinj stands out again $\left(2,947^{\circ} \mathrm{C}\right)$, and is near a value for the class $\mathrm{H}+3$.

During the research period (2005 to 2007) the $\mathrm{HI}$ for all sub-regions was over $3,000 \mathrm{C}^{\circ}$ units, and thus, they may belong to the $\mathrm{H}+3$ class. Podgorica has a particularly high value of $3,667 \mathrm{C}^{\circ}$ units.

The Bioclimatic Index is used to define the potential conditions for the cultivation of grapes (Avramov, 1991). It usually concerns zones with a temperate climate, because it considers rainfall an unfavorable factor for quality production (Buzatu and Maracineanu, 2015). It includes the effect of temperature, sunshine, rainfall and the duration of the growing season.

As Irimia et al. state (2013), the index varies between 4 and 15 , and is optimal if it is $10 \pm 5$. Values between 4 and 6 suggest an abundance of water, and values between 12 and 15 the abundance of heat in the area under study. More specifically, values above 10 indicate the influence of the continental climate, and below 10 that the climate is affected by the sea. We believe that the index cannot rightly point to favorable conditions for grape cultivation in Montenegro, although the shown values are within the so-called optimum (10 \pm 5 ). The sub-regions (Herceg Novi, Danilovgrad and Virpazar) that have a higher amount of rainfall have a lower coefficient $(5.73,6.23$ and 4.93 respectively).

\section{Grapevine phenology}

The data relating to the average dates for the occurrence of particular phenophases (budburst, blooming, véraison, harvest, leaf falling) for the period 2005 to 2007 is presented in Table 5.

In monitored areas, on average, the appearance of budburst ranged from 03-29 to 0402 , with the exception of sub-regions including Virpazar (location Ovtočići), Podgorica (location Ubli) and Danilovgrad (location Ostrog) that are located at higher altitudes ( $>350 \mathrm{~m})$, and where the budburst appeared from 04-05 to 04-08. Due to the lower temperatures, the activation of buds at higher altitudes was delayed by 7 to 10 days when compared with locations at lower altitudes.

The average start of blooming was also uniform (from 05-26 to 05-28), except for locations at higher altitudes (from 06-02 to 06-05).

In the examined period (2005 to 2007), véraison, on average, appeared from 07-10 to 0715 at all locations.

In the sub-regions of Podgorica and Ulcinj, grapes, on average, accumulated a sugar level of $21^{\circ} \mathrm{Bx}$ significantly faster than in other areas. The harvesting was carried out on 09-01 and on 09-03. In the sub-regions of Herceg Novi, Bar, Virpazar (location Godinje) and Danilovgrad (location Lower Martinići), it was carried out from 09-05 to 09-08. On average, in the sub-region of Virpazar (location Ovtočići) the harvest was performed on 09-17, and in the sub-region of Podgorica (location Ubli) and Danilovgrad (location Ostrog) only on 09-20.

Duration of the individual phonological stages is shown in Table 6.

The longest interval between budburst and blooming was recorded in the sub-region of Podgorica (location Ubli) and lasted 61 days. The period between blooming and véraison ranged from 40 to 47 days. The shortest period 
Table 6. Number of days in each phenological stage for different locations (2005 to 2007)

\begin{tabular}{ccccccc}
\hline Location & $\begin{array}{c}\text { Number } \\
\text { of days } \\
\text { (budburst- } \\
\text { blooming) }\end{array}$ & $\begin{array}{c}\text { Number } \\
\text { of days } \\
\text { (blooming } \\
\text {-verasion) }\end{array}$ & $\begin{array}{c}\text { Number } \\
\text { of days } \\
\text { (véraison- } \\
\text { harvesting) }\end{array}$ & $\begin{array}{c}\text { Number } \\
\text { of days } \\
\text { (blooming- } \\
\text { harvesting) }\end{array}$ & $\begin{array}{c}\text { Number } \\
\text { of days } \\
\text { (budburst- } \\
\text { harvesting) }\end{array}$ & $\begin{array}{c}\text { Number } \\
\text { of days } \\
\text { (budburst- } \\
\text { leaf fall) }\end{array}$ \\
\hline Herceg Novi & 58 & 45 & 56 & 101 & 159 & 230 \\
\hline Bar & 58 & 44 & 57 & 101 & 159 & 229 \\
\hline Ulcinj & 58 & 45 & 55 & 100 & 158 & 230 \\
\hline Virpazar/ Godinje & 56 & 46 & 56 & 102 & 158 & 225 \\
\hline Virpazar/Ovtocici (300 m alt.) & 57 & 42 & 65 & 107 & 163 & 215 \\
\hline Podgorica/Balijače & 57 & 44 & 53 & 97 & 154 & 228 \\
\hline Podgorica/Ubli (470 m alt.) & 61 & 40 & 68 & 108 & 169 & 221 \\
\hline Danilovgrad/Donji Martinići & 57 & 47 & 55 & 102 & 159 & 224 \\
\hline Danilovgrad/Ostrog (400 m alt.) & 58 & 40 & 67 & 107 & 165 & 216 \\
\hline
\end{tabular}

Table 7. Mean values and standard deviations of numbers of clusters per fruiting cane, clusters per fruiting cane, clusters and pruning weight (2005-2007)

\begin{tabular}{ccccccc}
\hline Grape characteristics & $\begin{array}{c}\text { No. of } \\
\text { buds }\end{array}$ & $\begin{array}{c}\text { Clusters } \\
\text { per fruiting } \\
\text { cane }\end{array}$ & $\begin{array}{c}\text { Clusters } \\
\text { per vine }\end{array}$ & $\begin{array}{c}\text { Cluster } \\
\text { weight } \\
\text { (g) }\end{array}$ & $\begin{array}{c}\text { Pruning } \\
\text { weight } \\
\text { (kg) }\end{array}$ & $\begin{array}{c}\text { Fruit/ } \\
\text { pruning } \\
\text { ratio }\end{array}$ \\
\hline Location & & & & & & \\
\hline Herceg Novi & 20 & 1.31 & 19.65 & 229 & $1.02 \mathrm{a}$ & 4.4 \\
\hline Bar & 20 & 1.33 & 19.95 & 222 & $0.99 \mathrm{a}$ & 4.5 \\
\hline Ulcinj & 20 & $1.45 \mathrm{a}^{*}$ & $21.45 \mathrm{a}$ & $241 \mathrm{a}$ & $0.97 \mathrm{a}$ & 5.3 \\
\hline Virpazar/Godinje & 20 & 1.29 & 18.06 & 230 & $0.92 \mathrm{a}$ & 4.5 \\
\hline Virpazar/Ovtocici (300 m alt.) & 20 & 1.19 & 17.38 & $212 \mathrm{~b}$ & 0.88 & 4.2 \\
\hline Podgorica/Balijače & 20 & $1.44 \mathrm{a}$ & $21.6 \mathrm{a}$ & $246 \mathrm{a}$ & $0.99 \mathrm{a}$ & 5.4 \\
\hline Podgorica/Ubli (470 m alt.) & 20 & $1.16 \mathrm{~b}$ & $17.24 \mathrm{~b}$ & $201 \mathrm{~b}$ & $0.73 \mathrm{~b}$ & 4.7 \\
\hline Danilovgrad/Donji Martinići & 20 & 1.27 & 17.78 & 224 & 0.85 & 4.7 \\
\hline Danilovgrad/Ostrog (400 m alt.) & 20 & $1.15 \mathrm{~b}$ & $17.1 \mathrm{~b}$ & $199 \mathrm{~b}$ & $0.71 \mathrm{~b}$ & 4.8 \\
\hline Average & 20 & 1.29 & 18.66 & 222.67 & 0.89 & 4.7 \\
\hline Cv\% & & 14.25 & 27.40 & 28.30 & 15.66 & \\
\hline LSD & & 0.27 & 4.1 & 31.4 & 0.19 & \\
\hline 0.05 & & & & &
\end{tabular}

*Values designated by a different letter within the same column differ significantly with a $0.05 \%$ significance level

was recorded in the sub-region of Danilovgrad (location of Ostrog) and the longest in the subregions of Ulcinj and Herceg Novi. The interval between véraison and harvesting varied between 53 and 68 days; in locations at higher altitudes it lasted 64 days (Virpazar/ Ovtočići), 67 days (Danilovgrad/Ostrog) and 68 days (Podgorica/ Ubli).

The period between budburst and harvesting was almost identical for five sub-regions (158 to 159 days), except for Podgorica, which is the warmest area, with extremely high temperatures $\left(41.3^{\circ} \mathrm{C}\right)$ during the summer and where the same period was four days shorter (154). In locations at higher altitudes this period was longer and lasted, on average, from 163 days (Virpazar/Ovtocici) to 169 days (Podgorica/Ubli).

The growing season (from budburst to leaves falling) lasted from 215 days (Virpazar/Ovtocici) to 230 days (Ulcinj, Herceg Novi). 
Table 8. Wine composition and wine-tasting score for different locations (2005 to 2007)

\begin{tabular}{cccccccc}
\hline & \multicolumn{7}{c}{ Wine composition } \\
\hline Location & $\begin{array}{c}\text { Specific } \\
\text { gravity }\end{array}$ & $\begin{array}{c}\text { Alcohol } \\
\text { (\% by } \\
\text { volume) }\end{array}$ & $\begin{array}{c}\text { Total } \\
\text { extract } \\
\text { (g/L) }\end{array}$ & $\mathrm{pH}$ & $\begin{array}{c}\text { Total } \\
\text { acidity } \\
\text { (g/L) }\end{array}$ & $\begin{array}{c}\text { Volatile } \\
\text { acidity } \\
\text { (g/L) }\end{array}$ & $\begin{array}{c}\text { Wine- } \\
\text { tasting } \\
\text { score } \\
(100 \\
\text { points) }\end{array}$ \\
\hline Herceg Novi & 0.9926 & 12.10 & 25.8 & 3.55 & $4.9 \mathrm{~b}$ & 0.54 & 82.1 \\
\hline Bar & 0.9934 & 12.10 & 26.1 & 3.33 & $4.7 \mathrm{~b}$ & 0.77 & 83.1 \\
\hline Ulcinj & 0.9951 & $12.35 \mathrm{a} *$ & $27.2 \mathrm{a}$ & 3.35 & $4.7 \mathrm{~b}$ & 0.81 & 84.5 \\
\hline Virpazar/Godinje & 0.9944 & 11.85 & 25.7 & 3.41 & $5.1 \mathrm{~b}$ & 0.45 & 84.2 \\
\hline Virpazar/Ovtocici (300 m a.s.l.) & 0.9912 & 11.75 & $22.1 \mathrm{~b}$ & 3.42 & $5.9 \mathrm{~b}$ & 0.55 & 82.2 \\
\hline Podgorica/Balijače & 0.9937 & 12.20 & $26.7 \mathrm{a}$ & 3.45 & $4.9 \mathrm{~b}$ & 0.71 & 85.6 \\
\hline Podgorica/Ubli (470 m a.s.l.) & 0.9911 & $11.68 \mathrm{~b}$ & $21.9 \mathrm{~b}$ & 3.52 & $6.2 \mathrm{a}$ & 0.51 & 81.2 \\
\hline Danilovgrad/Donji Martinići & 0.9959 & 11.95 & 25.2 & 3.38 & $5.0 \mathrm{~b}$ & 0.67 & 83.3 \\
\hline Danilovgrad/Ostrog (400 m a.s.l.) & 0.9918 & 11.75 & $22.3 \mathrm{~b}$ & 3.51 & $6.3 \mathrm{a}$ & 0.59 & 79.5 \\
\hline Average & 0.9932 & 11.97 & 24.78 & 3.44 & 5.30 & 0.62 & 82.86 \\
\hline Cv\% & - & 6.71 & 10.1 & - & 5.1 & - & - \\
\hline LSD & - & 0.65 & 4.41 & - & 0.88 & - & - \\
\hline
\end{tabular}

*Values designated by a different letter within the same column are differ significantly at a $0.05 \%$ significance level

\section{Grape}

The number of clusters per fruiting cane and the number of clusters per vine (Table 7) were significantly higher in the locations of Ulcinj and Podgorica (Balijača) compared to Podgorica (Ubli) and Danilovgrad (Ostrog). Also, for the same locations, as well as for Virpazar (Godinje) we have a significant difference in the average weight of the clusters. And at lower altitudes, the clusters were on average significantly heavier. These results are similar to the results obtained by Ulićević (1966).

For every location, the average pruning weight was $0.89 \mathrm{~kg}$ per vine. Only in two locations Podgorica (Ubli) and Danilovgrad (Ostrog), which were at higher altitudes - was the vegetative growth considerably lower compared to the locations by the sea and in Podgorica (Balijaca).

On average, the fruit/pruning ratio was 4.7, which means that for $1 \mathrm{~kg}$ of vegetative growth the vine produced $4.7 \mathrm{~kg}$ of grapes. The vegetative growth was significantly lower in locations at higher altitudes (Ubli and Ostrog) compared to the other locations.

\section{Wine}

In all the samples of wine the specific gravity was below 0.995 and as such they were classified as dry wines (Table 8). The alcohol content varied from sub-region to sub-region. The highest alcohol content was in wines from the coast (sub-regions: Ulcinj, Bar and Herceg Novi) and Podgorica (Lake Skadar basin). Similar results are reported by Burić (1995). According to the alcohol content, the wines from the location of Ulcinj (the southernmost location in Montenegro) were significantly different to the wines from Podgorica (Ubli).

Similar results were obtained from the content of the total extract. So, wines from Ulcinj and Podgorica, on average, had the highest extract (27.2 and $26.7 \mathrm{~g} / \mathrm{L}$ ). Wines from higher altitudes have a lower content of extract (21.9 to $22.3 \mathrm{~g} / \mathrm{L}$ ). The total wine extraction showed a significantly higher alcohol content in Ulcinj and Podgorica (Balijača) than the wines from Podgorica (Ubli) and Danilovgrad (Ostrog), while total acid content showed the opposite tendency: there was a significantly higher acid content in the wine from the lower-altitude locations of Podgorica (Ubli) and Danilovgrad (Ostrog) compared to all the other locations. The $\mathrm{pH}$ varied within the range of 3.35 to 3.55. Based on the content of volatile acids, all the wines were in good condition.

The average scores at wine-tasting competitions indicate that wine from Podgorica had the best organoleptic properties (85.6). Wine from 
Ulcinj also scored highly (84.5 points), as well as wine from the location of Godinje (84.2).

\section{Conclusions}

This research identified the climatic parameters for the Montenegrin viticulture area, the phenology of the most widespread Montenegrin indigenous grapevine variety - Vranac, and the chemical characteristics of Vranac wine. According to the data, Vranac varieties respond well to lower altitudes and sunny slopes. At higher altitudes there is less vegetative growth, and more acids accumulate in the grape, making the wine insufficiently harmonious. At these locations, the vine should not be burdened with a larger number of fruiting canes and yield.

The overall results indicate that the climate in the entire Montenegrin viticultural area is relatively uniform. The sum of effective temperatures and the duration of sunshine are sufficient for varieties that ripen in different periods, except for very late-ripening grapevines, because the periods of precipitation that start in October and the decrease in the mean daily temperatures lead to a longer ripening period for grapes at higher altitudes. During the winter and the growing season, there is no danger of frost damage to the vines. Humidity is not a problem in terms of the onset of disease. Precipitation follows a Mediterranean pattern - heavy rainfall between October and January and then again, but for a shorter period, in the early spring (March to April). In the summer, the amount of precipitation drops, and it is necessary to irrigate vineyards.

In all the viticultural areas the phenological stages of grapevine growth are uniform, with small oscillations ( 2 to 3 days). Noticeable changes in the phenology and the chemical composition of the wine occur in vineyards situated at higher altitudes (Ovtočići, Ubli, Ostrog). The results indicate that harvesting in these locations was delayed by 17 to 19 days in comparison with Podgorica (location Balijače) which had the earliest harvesting date.

Grapes from the coastal region and sub-region of Podgorica (Lake Skadar basin) are generally characterized by rapid ripening, a high sugar content and lower acidity. Wines are full-bodied and rich in alcohol, but sometimes dull due to the lower total acid content. In wines from locations at higher altitudes a higher acidity level, lower alcohol content and total extracts dominate.
Generally, the coastal region has almost the same climatic parameters, and phenological cycle of the Vranac variety is uniform in all the locations. Among the sub-regions on the coast, Ulcinj, due to its thermal conditions, can be recommended for the cultivation of all grape varieties.

The Lake Skadar basin is not so uniform regarding its climate parameters. Podgorica is distinctive due to its thermal conditions. Podgorica, like Ulcinj, is recommended for the cultivation of all grape varieties, from the earlyto the late-ripening varieties. The locations of Danilovgrad and Virpazar (lower altitude) are not recommended for the late-ripening varieties. These locations were modified by the influence of Lake Skadar (Virpazar) and the northern mountain ranges (Danilovgrad)

Early-ripening varieties are recommended for locations at higher altitudes, but only if they are situated in places facing south or south-west.

Due to having almost the same climatic parameters, we think that the official zoning needs to be changed. We suggest that there should no longer be any regions (the Coast and Lake Skadar), but just one Montenegrin region, with precise definition of the vineyards and localities in them (such as Podgorica or Ulcinj, or those at higher altitudes) which, due to the influence of climatic and mesoclimatic parameters, soil and ampelographical techniques, produce grapes and wine of a certain composition.

\section{References}

1. Amerine MA, Winkler JAR (1944). Composition and quality of musts and wines of California grapes. Hilgardia 15: 493-673.

2. Antoce AO, Nămoloúanu I, Cazacu S, Ivaşcu M, Dumitru E (2007). Evaluation of the productive potential for ecological production of three Romanian vine growing centres. World Congress of Vine and Wine, OIV. Budapest, June 10-16, Budapest, Hungary

3. Avramov L, 1991. Vinogradarstvo. Nolit, Beograd.

4. Branas J (1974). Viticulture. Imp. Déhan, Montpellier.

5. Bulić S (1949). Dalmatinska ampelografija, Poljoprivredni nakladni zavod, Zagreb.

6. Burić D (1995). Savremeno vinogradarstvo, Nolit, Beograd.

7. Buzatu GD, Maracineanu LK (2015). Evaluation of levels of climate favorability for viticulture in Breasta viticultural area. Acta, Universitatis Cibinienis, 67(1): 105-110.

8. Carbonneau A (2000). Climat et sol: critères d'évaluation et effets sur le comportement de la vigne. In:V. Sotés (ed.). 
Proc. $3^{\circ}$ Simp. Int. Zonificación vitivinícola, May 2000, Tenerife (Spain). CD-ROM.

9. Carbonneau A (2003). Ecophysiologie de la vigne et terroir. Terroir, zonazione, viticoltura. Trattato internazionale. Phytoline 1: 61-102.

10. Constantinescu G (1970). Ampelografia republiici socialiste România. Editura Academiei R.S.R, Bucureşti.

11. Dokoozlian NK (1996). Influence of light on grape berry growth and composition varies during fruit development. J. Amer. Soc. Hort. Sci. 121(5): 869-874.

12. Falcetti M (1994). Le terroir. Qu'est-ce qu'un terroir? Pourquoi l'étudier? Pourquoi l'enseigner? Bull. OIV 67(2): 246-275.

13. Fraga, H., Malheiro, A.C., Moutinho-Pereira, J., Santos, J.A., 2013. Future scenarios for viticultural zoning in Europe: ensemble projections and uncertainties, International Journal of Biometeorology, 57(6): 909-925.

14. Fuštić B, Đuretić,G (2000). Zemljišta Crne Gore, Univerzitet Crne Gore, Podgorica.

15. Grupa autora (1977). Rejonizacija vinogradarstva SR Crne Gore, Univerzitet Veljko Vlahović, Titograd.

16. Huglin P (1978). Nouveau mode d'évalution des possibilités héliothermiques d'un milieu viticole. Comptes Rendus de l'Academie de l'Agriculture de France, 64: 1117-1126.

17. Irimia L, Patriche CV, Quénol H (2013). Viticultural zoning: a comparative study regarding the accuracy of different approaches in vineyards climate suitability assessment. Cercetări Agronomice in Moldova, Vol. XLVI(3): 155.

18. Jelaska M (1954). Osnovi vinogradarstva na Primorju, Zagreb.

19. Santos JA, Malheiro AC, Pinto JG, Jones GV (2012). Macroclimate and viticultural zoning in Europe: observed trends and atmospheric forcing, Climate Research, 51: 89-103.

20. Jones VG, White AM, Cooper RO, Storchmann K (2005). Climate Change and Global Wine Quality, Climatic Change, 73(3): 319-343.

21. Jukić V, Drenjančević M, Horvat D, Vršič S, Brmež M, (2013). Biometrijska procjena značaja nekih ampelotehničkih zahvata na cv. Zweigelt (Vitis vinifera L.) u vinogorju Feričanci, Poljoprivreda 19(2): 3-9.

22. Köse B (2014). Phenology and Ripening of Vitis vinifera L. and Vitis labrusca L. Varieties in the Maritime Climate of Samsun in Turkey's Black Sea Region.

23. Law on Wine (2007). Službeni list Crne Gore. br. 01$776 / 2$, Podgorica.

24. Lebon E (1993). De l'influence des facteurs pédo- et mésoclimatiques sur le comportement de la vigne et les caractéristiques du raisin. Application à l'établissement de critères de zonage des potentialités qualitatives en vignoble à climatsemi-continental (Alsace). PhD Thesis, Dijon University, 21000 Dijon, France.

25. Madruga J (2015). Interactive comment on "Analysis and definition of potential new areas for viticulture in the Azores (Portugal)". Soil Discuss, 1, C604-C630
26. National Bureau of Statistics (2014). Poljoprivreda i ribarstvo. Monstat, Podgorica.

27. Neumann AP, Matzarakis A (2011). Viticulture in southwest Germany under climate change conditions. Climate research, 47: 161-169.

28. OIV (1994). International wine competition standard. International organisation of Vine and Wine, Paris.

29. OIV (2001). Code des caractères descriptifs des variétés et espèces de Vitis $2^{\text {éme }}$ édition. Organisation Internationale de la Vigne et du Vin, Paris.

30. OIV (2004). International Code of Oenological Practices. Organisation Internationale de la Vigne et du Vin, Paris.

31. Party JP, Duchaufour H, Revol P, Thaler A (1990). Les unités de paysage et les sols du vignoble alsacien. Cartographie au 1/25000ème. GIE Sol Conseil, Association pour la Relance Agronomique en Alsace,Comité Interprofessionnel du Vin d'Alsace (eds). Private report. Strasbourg-Colmar, France.

32. Popescu SM (2011). Evaluation of the climatic conditions of Banu Mărăcine Viticultural Centre. Journal of Horticulture, Forestry and Biotechnology, 15(1): 67- 71.

33. Ravaz L (1912). Taille hative du taifle tardive, Montpellier.

34. Santos AJ, Malheiro CA, Pinto GJ, Jones VG (2012). Macroclimate and viticultural zoning in Europe: observed trends and atmospheric forcing. Climate research, 51: 89-103.

35. Savić S, (2004a). Rejonizacija vinogradarstva u Crnoj Gori I. Matica, Matica crnogorska, Cetinje, 19: 241-279.

36. Savić S (2004b). Rejonizacija vinogradarstva u Crnoj Gori II. Matica, Matica crnogorska, Cetinje, 20: 423-425.

37. Savić S, Petranović N (2004). Impact of pruning and bud loading on "Grenache" grape and wine quality in Podgorica Vine District. ISHS, Acta.Hortic., 652: 217-221.

38. Savić S (2016). Crnogorska ampelografija. CANU, Podgorica.

39. Seljaninov GT (1966). Agroclimatic Map of the World. Hydrometeoizdat Publishing House, Leningrad.

40. Shanmuganathan S (2010). Viticultural Zoning for the Identification and Characterisation of New Zealand “Terroirs" Using Cartographic Data. GeoCart'2010 and ICA Symposium on Cartography.

41. Skelton S (2009). Viticulture: an introduction to commercial grape growing for wine production. Perfect Paperback, London.

42. Sotés V, Gómez-Sanchez P, Laya H, Gómez-Miguel V (1994). Cuantificación de las variables implicadas en la delimitación y caracterización dezonas vitícolas en la D.O Ribera del Duero. In:7th GESCO, 21-23 July 1994, Valladolid, Spain. (pp. 248-256).

43. Škorić A, Filipovski G, Ćirić M (1985). Klasifikacija zemlljišta Jugoslavije. Akademija nauka i umjetnosti Bosne i Hercegovine, Sarajevo.

44. Tonietto J, Carbonneau A (2004). A multicriteria climatic classification system for grape-growing regions worldwide. Agricultural and Forest Meteorology, 124(12): 81-97.

45. Tesic T, Woolley DJ, Hewett EW, Martin DJ, (2010). Environmental effects on cv Cabernet Sauvignon (Vitis 
vinifera L.) grown in Hawke's Bay, New Zealand.: 1. Phenology and characterisation of viticultural enviroments. Aust. Journal of Grape and Wine Research , 8(1): 15-26.

46. Ulićević M (1959). Prilog rejonizaciji vinogradarstva u Crnoj Gori. Naša Poljoprivreda, 2/4, Titograd.

47. Ulićević M (1966). Prilog proučavanju osobina najvažnijih sorti vinove loze gajenih u SR Crnoj Gori, Beograd.
48. Vaudour E (2003). Les terroirs viticoles. Définitions, caractérisation et protection, Dunod, Paris.

49. Vaudour E, Shaw AB (2005). Worldwide Perspective on Viticultural Zoning, S. Afr. J. Enol. Vitic., 26(2).

50. White ER (2003). Soils for fine wines. Oxford University Press, New York.

51. Winkler JA, James AC, Kliewer MW, Lider AL (1974). General viticulture. University of California Press, Barkeley. 